\title{
07
}

\section{IMPACT ASSESSMENT OF WATER RESOURCE AND PEOPLES' PERCEPTIONS, TARANAGAR BLOCK (CHURU) RAJASTHAN}

\author{
M. M. Sheikh \\ Associate Professor (Geography) \\ Government Lohia College, Churu (Rajasthan), India \\ Email:mmskh@rediffmail.com
}

\begin{abstract}
The next world war will be fought over fresh water or Water will be a major source of conflict between nations and communities in this century are statements heard in different permutations in practically every freshwater related event or gathering. Water is an essential source for the sustenance of all life forms in our planet and with every passing day the demand for freshwater outpaces its availability. This growing scarcity is alarming but such doomsday predictions are not a solution. Science and technology is looking for ways to increase the supply of freshwater but we must also pause and reflect on the ways of our forefathers in harvesting freshwater that sustained them through millenniums in various ecological systems. Historically Indians have been the world's greatest water harvesters. Be it rainwater, groundwater, floodwater or water from streams and rivers, Indians over centuries developed a wide range of systems for harvesting, storage, utilization and ground recharge in different ecological regions. These systems beautifully blended \& complimented the culture of the concerned regions. But for various reasons they were abandoned. Today, in our country, with each passing day the need to sensibly harvest \& use freshwater is increasing manifold. For this we all have to in the words of Maude Barlow, radically restructure our societies and lifestyles to reverse the trend of depleting freshwater from earth".
\end{abstract}

\section{Introduction}

Water was a symbol of significance in the history of ancient civilizations that prospered close to it. Unlike the urban industrialized civilizations of 21 st century most humans throughout history knew that freshwater resources would run out unless water is harvested and conserved. Available fresh water is only one half of one percent of total fresh water available on earth, still modern day humans, convinced of their supremacy over nature, have failed to revere water though the dependence on it, of all life forms, for sustenance is still as much as it was in ancient times. Water is an essential natural resource; a key building block of life. However, water use has grown at over twice the population growth rate in the last century. As a result, an increasing number of regions are now chronically short of water. Over 1.4 billion people currently live in river basins where use of water exceeds minimum recharge levels. In the Second World Water Forum, The Hague in March 2000 estimated that a 17 percent increase in water consumed by irrigated agriculture would be necessary to provide for the nutritional needs of a world population likely to rise to somewhere between 7 and 111 billion by the year 2015 .

Rajasthan needs more holistic and integrated management of its water resources. Collective action is necessary to bring together the public sector, the private sector, civil society, and other stakeholders to work together towards integrated and participatory solutions for water resources planning and management. Studies have shown Rajasthan is among regions with greatest climate sensitivity and lowest adaptive capability. Rajasthan has only 1.16 percent of the country's total surface water resources or 21.71 billion cubic meters (BCM), however $16.05 \mathrm{BCM}$ of this is economically usable. The state has created capacity to harness and store $11.29 \mathrm{BCM}$, or around 70 percent of available water. The state has 1.72 percent of the country's groundwater, translating into $11.36 \mathrm{BCM}$. Dependent on inflows into the rivers, 17.88 BCM is allocated through inter-state agreements, although not dependable due to political compulsions of the upper riparian states. On paper, water use can be expanded by a further 30 percent. However more realistic assessment of additional availability is economically usable water or 21 percent. This is broken down in figure below, which accounts for the use of 79 percent of the $45.09 \mathrm{BCM}$ of economically available water. 


\section{Churu District Water Scenario}

The district is characterized by undulating sand-dunes and inter-dunal sandy planes, except towards south eastern part where few isolated hillocks of considerable height but restricted extension are exposed. Fairly open \& flat topography has also been observed in Rajgarh and Sujangarh blocks. Practically there is no river in the district: however, in extremely high rainy season Kantly River enters in the district from extreme southern peripheral village of Rajgarh block. Semi-desertic to desertic climatic conditions are typical characteristics of the district. In extreme summer season, the temperature rises up to $49^{\circ} \mathrm{C}$ or even more sometimes, while in extreme winters it falls down below the freezing point. Rainfall is also low and erratic with an average annual rainfall of $415.77 \mathrm{~mm}$ in the year 2019. The normal rainfall of the district is $353.76 \mathrm{~mm}(1901-2018)$.

Younger and older alluvium of quaternary age, Tertiary sandstones, Nagaur sandstones, Bilara limestone, Jodhpur sandstones, and weathered granite and gneisses are the main water bearing formation encountered in the district. Ground water generally occurs under un- confined to semi- confined conditions. Depth to water in the district generally ranges between 6.67 to 91.05 meters below ground- level. Water table generally shows a depletion trend in almost all ground water potential zones while a rising trend is observed in ground water saline zones. Average discharge of well (dug-cum-bored wells and tube-wells) constructed in the district ranges between 1,500 to 4,500 gallons per hour. Chemical quality of ground water in ground water potential zones is fresh to semi- saline with electric conductivity ranging between 1,000 to 6000 micro Siemens/cm. Quality of ground water in ground water saline zones saline to extremely saline with electric conductivity ranging between 6000 to 24,000 micro Siemens/cm.

As per the revised guide-lines of the Ground Water Estimation Committee 2017, instead of individual ground water potential zone, the block as a whole has been assessed and categorized on the basis of stage of ground water development and long term trend of watertable. Out of seven blocks of the district, one block Sardarshahar has been categorized as "SAFE", one Ratangarh as "SEMI-CRITICAL", and three blocks Rajgarh, Sujangarh and Bidasar have been characterized as "OVER-EXPLOITED". Block Taranagar has saline native ground water and has not been assessed. (Hydrogeological report of Rajasthan, Churu District)

\section{Study Area}

Taranagar Tehsil is situated in Churu District of Rajasthan State, India. It is located $48 \mathrm{~km}$. towards North from District headquarters Churu. Taranagar is situated at $28^{\circ} 41^{\prime} \mathrm{N} 75^{\circ} 3^{\prime} \mathrm{E}$, about 120 miles northeast of Bikaner. Taranagar was earlier known as Reni. It has an average elevation of 232 meters. According to Census 2011 the population of tehsil is 2,11,831. There are 123 villages in Taranagar block. Taranagar tehsil is very water consuming tehsil in agriculture sector. The ground water is brackish but still people are using this water. Due to over exploitation the ground water gone very deep and the tehsil has been declared as dark zone block. There is an urgent need to study the area to know the factual position of the tehsil. Total area of Taranagar block is falling in a single scene of landsat 7 and 8 having path and row numbers 148-40 respectively. High resolution LISS IV data and CartoSAT pancromatic data have also been acquired for land use analysis and validated through filed check. Standard false colour composite (FCC) images composed of green, red and infrared bands have been used for identification of features and land use classes, selection of suitable training sites for supervised classification. Careful study of satellite images shows that the study area is mainly sandy in nature. Major land use category is agriculture land which covers about 90 percent of the Taranager block remaining 10 percent area is covered by settlement, pasture land, waterbodies etc. Total area of Taranager block measured by GIS software is $1825.75 \mathrm{sq}$. kms. out of which 1630.6 is the crop land.

\section{Objectives}

To identify the impact assessment of water resource and peoples' perceptions, of Taranagar block of Churu district.

\section{Methodology}

The study has been mainly based on primary and secondary data. The intensive primary data has been collected from 30 villages of Taranagar block. Apart from this mist of all villages 
visited by researcher and got some broad ideas about the water issues and present scenario in the block. From each of the selected villages about 10 to 20 percent household were surveyed and public consultations. Total 500 household were interviewed for collect primary data. Number of household was selected on the basis of number of population of the villages. It varies from 5 to 50 household. Some basic secondary data were also collected from State Ground Water Department and other sources.Basic maps were prepared with the help of Department of Remote Sensing, Birla Institute of Scientific Research, Jaipur. Taranagar development block of Churu district is located in northern part of the district.

\section{Figure 01: Study Area Key Map}

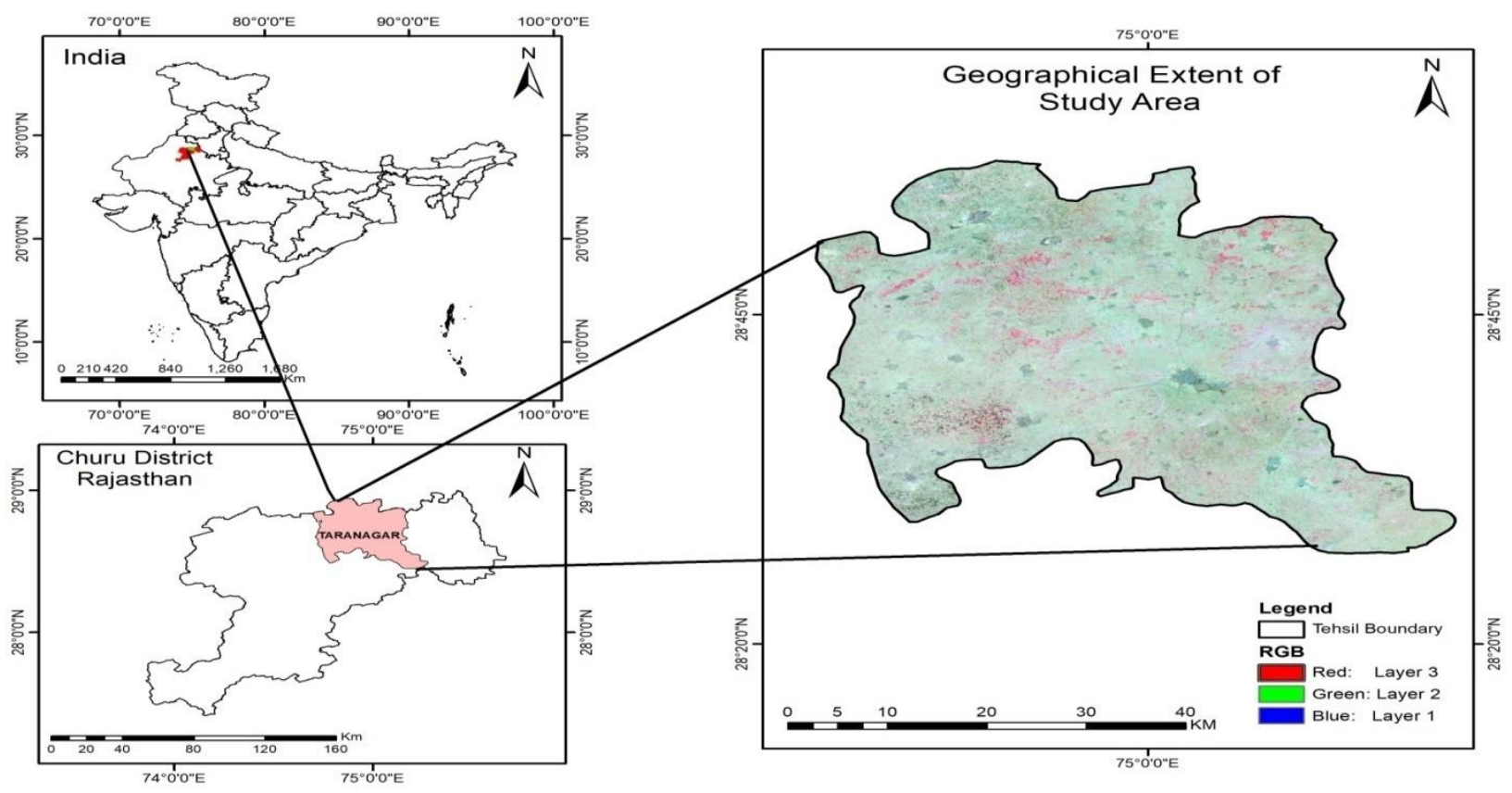

\section{Rainfall}

The average annual rainfall in the district is $429 \mathrm{~mm}$. In general there are 22 rainy days (i.e. days with rain of $2.5 \mathrm{~mm}$ or more) in a year. About 7.5 percent of the annual rainfall is received during the South-West monsoon period. Highest rainfall of 2018 is $97 \mathrm{~mm}$. The variation in the rainfall from year to year is very large. The analysis of 18 years average monthly rainfall data shows that there is negative relationship between the amount of monthly rainfall and its variability. The rainy days are of very short time i.e. from July to half of September. Maximum amount of rainfall depends upon the Arabian monsoon. January is the coldest month of the winter season. During this period, temperature falls below the freezing point. In winter season the wind blows from the north-east to south-west. The relative humidity during this season varies from 25 percent to 83 percent. The sand storms are common feature in summer.

Table 02: Range Of Depth to Water in Various Water in Various Blocks (Pre- Monsoon 2003 to Post-Monsoon 2017)

\begin{tabular}{|l|c|c|}
\hline \multirow{2}{*}{ Water Bearing Formation } & \multicolumn{2}{c|}{ Depth of Water (b.g.I.) in MTS } \\
\cline { 2 - 3 } & Minimum & Maximum \\
\hline Churu & 24.04 & 47.89 \\
\hline Rajgarh & 13.67 & 54.45 \\
\hline Ratangarh & 22.88 & 92.27 \\
\hline Sardarshahar & 24.83 & 91.05 \\
\hline Sujangarh & 06.67 & 84.45 \\
\hline Taranagar & 16.07 & 29.17 \\
\hline
\end{tabular}

Source: District Ground Water Department, Churu

\section{Change in Ground Water Level}

The world community is facing challenges of water level in certain areas due to over withdrawing and demands of ground water. Water security is our main moral duty in the present context. The term 'water security' was used at the World Water forum in The Hague in 2000 to underline the vulnerability of people and ecosystems to ever growing pressure on the world's limited water resources (World Water Council, 2000). Groundwater, though part of hydrological cycle and a community resource, is still perceived as an individual property and is exploited 
inequitably and without any consideration to its sustainability leading to its over-exploitation in several areas. Awareness is now increasing regarding water and its importance but in general people misbehave when it comes to reducing wastage of water. Table 02 shows that about 65.6 percent people are aware that water level is changing very fast in this area due to over withdrawing of ground water. Though, water quality is not as per WHO standard. They are using water in agriculture and other domestic purposes. Whereas 25.6 percent people said that water level is not changing in this area. Because water is brackish and there is no use of water in any means. Apart from this 8.8 percent people indicated that they had no information of the change in ground water level. On an average about 60 percent of potable water is being drained as waste water, which is injustice for our mother earth.

Table 03: Change in Ground Water Level

\begin{tabular}{|l|c|c|}
\hline Response & No. of Persons & Percent \\
\hline Yes & 328 & 65.6 \\
\hline No & 128 & 25.6 \\
\hline No Response & 44 & 8.8 \\
\hline \multicolumn{1}{|c|}{ Total } & 500 & 100 \\
\hline
\end{tabular}

Source: Field Survey

\section{Water Quality}

The quality of water is directly related with human and animal health. If the water quality is not as per standard the mantle and physical problems will occur. The fluoride contents are very high in most of the villages of study area. The average nitrate concentration is $185 \mathrm{mg} / \mathrm{L}$. It shows that nitrate concentration is very high in this block. The hardness of water is also very high. The ground water quality in the study area is very low. The following table shows the response from the people regarding water quality. About 82.2 percent respondents believe that water quality in this area is not as per standard. About 6.4 percent reported that water quality is not an issue in this area. Whereas 11.4 percent respondents reported that they don't have any idea related to water quality issues in this area. [

Table 04: Water Quality

\begin{tabular}{|l|c|c|}
\hline Response & No. of Persons & Percent \\
\hline Yes & 411 & 82.2 \\
\hline No & 32 & 6.4 \\
\hline No Response & 57 & 11.4 \\
\hline Total & 500 & 100 \\
\hline
\end{tabular}

Source: Field Survey

\section{Unsafe for Drinking}

Safe and readily available water is important for public health, whether it is used for drinking, domestic use, food production or recreational purposes. Improved water supply and sanitation, and better management of water resources, can boost countries' economic growth and can contribute greatly to poverty reduction. Globally, at least 2 billion peoples drinking water source is contaminated with faeces. About 90 percent of the global population ( 6.8 billion people) used at least basic services. A basic service is an improved drinking-water source within a round trip of 30 minutes to collect water. In least developed countries, 22 percent of health care facilities have no water service, 21 percent have no sanitation service, and 22 percent have no waste management service. By 2025, half of the world's population will be living in water-stressed areas. Contaminated water can transmit diseases such diarrhea, cholera, dysentery, typhoid, and polio. Contaminated drinking water is estimated to cause 485000 diarrheal deaths each year. The following table shows that 86.4 percent people of the study area said that they are not getting potable drinking water. Only 2.2 percent are satisfied with present water supply quality. About 11.4 percent has not given any response.

Table 05: Unsafe for Drinking

\begin{tabular}{|l|c|c|}
\hline Response & No. of Persons & Percent \\
\hline Yes & 432 & 86.4 \\
\hline No & 11 & 2.2 \\
\hline No Response & 57 & 11.4 \\
\hline \multicolumn{1}{|c|}{ Total } & 500 & 100 \\
\hline
\end{tabular}

Source: Field Survey 


\section{Increasing Ground Water Demand}

As we know that ground water of the study area is saline and not useable for drinking and agricultural purposes. Only in some part of the area especially in Taranagar-Sahawa road people are using ground water for agricultural purposes. Only 6.8 percent people agreed that ground water demand is increasing. Whereas 77.4 percent people reported that ground water demand is not increasing due to its salinity. There is no any use of this water. Whereas 15.8 percent have not gave any response. Details are given in table 06.

Table 06: Increasing Ground Water Demand

\begin{tabular}{|l|c|c|}
\hline Response & No. of Persons & Percent \\
\hline Yes & 34 & 6.8 \\
\hline No & 387 & 77.4 \\
\hline No Response & 79 & 15.8 \\
\hline \multicolumn{1}{|c|}{ Total } & 500 & 100 \\
\hline
\end{tabular}

Source: Field Survey

\section{Knowledge about Water Supply System:}

Our government supply water in most of the rural and urban areas as per their need but people of the study area are not getting adequate and sufficient water supply. The scholar tried to find out whether who used to supply water in their area. The result shows that still most of the people don't know the particular water supply department in their areas. The result shows that 9.2 percent respondents said that ground water department supply potable water in their areas. About 15.4 percent people said that Public health and Engineering Department (PHED) are responsible for water supply in this area. About 33.8 percent said that Aapni yojna is supplying water in their area. Only 3.8 percent highlight the panchayat samiti. On the contrary 10.4 percent people reported that gram panchayat is supplying the water and about 18.8 percent of villagers are not aware who supply the drinking water in their area is. All this is due to lack of community participation in water supply system. Earlier Aapni yojna started the campaign to create awareness about water and sanitation but nowadays nobody knows confidently who is supplying the water in their area. Details are given in table 07.

\section{Table 07: Knowledge about Water Supply System}

\begin{tabular}{|l|c|c|}
\hline Response & No. of Persons & Percent \\
\hline Ground Water Department & 46 & 9.2 \\
\hline PHED & 77 & 15.4 \\
\hline Aapni Yojna & 169 & 33.8 \\
\hline Panchayat Samiti & 19 & 3.8 \\
\hline Gram Panchayat & 52 & 10.4 \\
\hline Any Other & 43 & 8.6 \\
\hline Don't Know & 94 & 18.8 \\
\hline \multicolumn{1}{|c|}{ Total } & 500 & 100 \\
\hline
\end{tabular}

Source: Field Survey

\section{Mismanagement and Misuses}

There is mismanagement and misuses of water through leakage because of lack of maintenance, poor quality infrastructure, lack of public participation and lack of sufficient and timely budget etc. Due to flexible policy implementation water mismanagement and misuses are very high. It was observed from the study that there was a low consciousness about the overall scarcity and economic value of water, which results in its wastage and inefficient use. About 40 percent respondents reported that due to lack of awareness 40 percent water misused in domestic sector, 60 percent in agriculture sector, 10 percent in industrial sector, 25 percent in commercial sector, 40 percent due to lack of proper and timely maintenance and 25 percent in other activities. In short, we can conclude there is huge that almost mismanagement and misuses in every sector. The results are given in table 08.

\section{Use of Water in Proper Way}

The following table shows the response of villagers related to use of water in proper way. About 59.2 percent villagers use water in proper way. They don't waste water other than domestic uses. About 35.2 percent villagers are not satisfied the use of water in proper way. They said that the villagers are using water in other than domestic use such as kitchen garden, construction, animal feeding etc. Only 5.6 percent people have been not given any answer. The details of water use in proper way are given in table 09. 
Table 08: Mismanagement and Misuses of Water Resources

\begin{tabular}{|l|c|}
\hline Category & Percent (Multiple Choice) \\
\hline Domestic Uses & 40 \\
\hline Agricultural Purposes & 60 \\
\hline Industrial Purposes & 10 \\
\hline Commercial Purposes & 25 \\
\hline Lack of Maintenance & 40 \\
\hline Other & 25 \\
\hline
\end{tabular}

Source: Field Survey

Table 09: Use of Water in Proper Way

\begin{tabular}{|l|c|c|}
\hline Response & No. of Persons & Percent \\
\hline Yes & 296 & 59.2 \\
\hline No & 176 & 35.2 \\
\hline No Response & 28 & 5.6 \\
\hline \multicolumn{1}{|c|}{ Total } & 500 & 100 \\
\hline
\end{tabular}

Source: Field Survey

\section{Knowledge of Ground Water Saline Zone}

Taranagar block comes under saline ground water zone. In most of the area water is not potable. Most of the people are aware that ground water of this area is very saline and not useful for any purposes. About 51 percent people reported that most of the people are well known that ground water of this area is saline and not potable. Whereas 32.8 percent people said that they don't know about the salinity of ground water in this area. About 16.2 percent people not given any response. Details are given in table 10.

Table 10: Knowledge of Ground Water Saline Zone

\begin{tabular}{|l|c|c|}
\hline Response & No. of Persons & Percent \\
\hline Yes & 255 & 51.0 \\
\hline No & 164 & 32.8 \\
\hline No Response & 81 & 16.2 \\
\hline Total & 500 & 100 \\
\hline
\end{tabular}

Source: Field Survey

\section{Increase of Ground Water Level}

The following table shows that ground water of this area can be changed through some best techniques. About 4.8 percent of the study area people said that ground water level can be increased through rain water harvesting. Ground water recharge well construction is also one of the best sources to increase ground water level. 15.6 percent people reported that ground water level can be increased through recharge well construction in the area. About 13.4 percent people reported that avoid using ground water in agriculture will also improve the ground water level. About 9 percent people supported this system. Canal water is also another best alternate to improve and increase the ground water. About 28.8 percent people have favored this issue. They also said more emphasis should be given on regular canal water supply for irrigation. About 10.8 percent people said that watershed scheme should be implemented in all villages of Taranagar block to optimum use of every drop of rainwater. Whereas 17.6 percent people reported that they don't have any idea about how to increase ground water level. Table 11 shows the details of respondents' responses.

Table 11: Increase of Ground Water Level

\begin{tabular}{|l|c|c|}
\hline Response & No. of Persons & Percent \\
\hline Rain Water Harvesting & 24 & 4.8 \\
\hline Ground Water Recharge Well Construction & 78 & 15.6 \\
\hline Avoid Using Ground Water in Agriculture & 67 & 13.4 \\
\hline Adopt Drip Irrigation System & 45 & 9.0 \\
\hline Regular Supply of Canal Water for Irrigation & 144 & 28.8 \\
\hline Implementation Watershed Scheme & 54 & 10.8 \\
\hline Don't Know & 88 & 17.6 \\
\hline \multicolumn{1}{|c|}{ Total } & 500 & 100 \\
\hline
\end{tabular}

Source: Field Survey 


\section{Irrigation Facility}

The irrigation facility is not satisfactory in the Taranagar block. Kumbharam Arya lift canal provided some water for irrigation in selected areas. The lift canal is connected with IGNP Canal. Government is trying to canal network in whole block but it will take more time. Only 5 percent respondents reported that irrigation facility is available. Canal irrigation is very limited due to slope and height of canal from ground level. Some people developed new technology to use this canal water. They dug $180 \times 180$ feet 'diggi' in their field. They bring water from canal through pipe line in this 'diggi'. They use this water in irrigation purposes. Eventually these become very costly. It costs comes around 15 lacs. Every farmer is not able to meet out this cost. On the other side 75 percent people said there is no irrigation facility available in the district. Ground water is brackish and canal network is covering only few villages. About 20 percent have not given any response (Table 12).

Table 12: Irrigation Facility

\begin{tabular}{|l|c|c|}
\hline Response & No. of Persons & Percent \\
\hline Yes & 25 & 5.0 \\
\hline No & 375 & 75.0 \\
\hline No Response & 100 & 20.0 \\
\hline \multicolumn{1}{|c|}{ Total } & 500 & 100 \\
\hline
\end{tabular}

Source: Field Survey

\section{Regular Use of Rainwater Structure (Tanka)}

Tankas' or 'kunds' are covered underground tanks in which people have being harvesting rainwater from rooftops or from a surrounding structured surface catchment area called "paitan" for hundreds of years. Kunds were primarily privately owned though rich businessmen \& rulers of the land as part of their pious contribution built many public kunds for the community. Construction of water structure was also considered to be one of the seven meritorious acts a person was expected to perform during a lifetime. The generosity of a rich family was judged in terms of number of water harvesting bodies sponsored by them. The public kunds built by them in villages served poor in the community who did not have the means to build one for their use.

The following table shows that nowadays people are not using rainwater properly or in a systemic ways. They use rainwater is different ways. At home only 11.4 percent people are using water for drinking purposes when supply water is not available. At their field 31.8 percent people are using rain water stored in kund or tanka. They have kund/tanks at their field. Whenever they visit their fields for agricultural purposes they use this water for drinking purposes. At public place there are number of tanks/kund constructed by gram panchayat or any local rich person but now they are not using this tanka/kund for any purposes due to its poor maintenance, low rainfall and water available at other sources. About 35.2 percent people said that they have kund/tanks at their home and field but they are not using because of poor maintenance and low rainfall. About 15.2 percent people have not given any response.

Table 13: Regular Use of Rainwater Structure (Tanka)

\begin{tabular}{|l|c|c|}
\hline Category & No. of Persons & Percent \\
\hline At Home & 57 & 11.4 \\
\hline At Field & 159 & 31.8 \\
\hline At Public Place & 32 & 6.4 \\
\hline No Use & 176 & 35.2 \\
\hline No Response & 76 & 15.2 \\
\hline \multicolumn{1}{|c|}{ Total } & 500 & 100 \\
\hline
\end{tabular}

Source: Field Survey

\section{Water Level Increase in Rainy Season}

Deserts are some of the most inhospitable places on earth. They are very dry, have very poor soil, and can experience wildly varying temperature extremes. Deserts are arid regions, generally receiving less than 25 centimeters (10 inches) of precipitation a year, or regions where the potential evaporation rate is significantly greater than the precipitation. In most cases, deserts possess a high average temperature with large differences between daytime and nighttime temperatures. Arid regions can also be defined as environments in which water is the limiting factor for bio-systems. The following table shows that 55.4 percent respondents feel that water level increases in rainy season, if rainfall comes. About 23 percent people said that no water level is increasing in this area due to low rainfall. Most of the area receives very less 
rainfall except in some particular years. About 21.6 percent people have not given any response (Table 14).

Table 14: Water Level Increase in Rainy Season

\begin{tabular}{|l|c|c|}
\hline Response & No. of Persons & Percent \\
\hline Yes & 277 & 55.4 \\
\hline No & 115 & 23.0 \\
\hline No Response & 108 & 21.6 \\
\hline Total & 500 & 100 \\
\hline
\end{tabular}

Source: Field Survey

\section{Rate of Ground Water Recharge}

The following table shows the 3 percent respondents reported that water level increases up to 5 feet if rainfall. About 7.4 percent people said that water level increases 1 to 4 percent during rainy season if raining sufficient quantity. About 11.2 percent said water level increases 1 to 3 percent if rainfall is more than average, whereas 23.6 percent reported that ground water level increases 1 to 2 feet in rainy season. Whereas 25.8 percent reported that water level increases up to 01 feet. About 11 percent people have no any idea about rate of ground water recharge. Details are given in table 15.

Table 15: Rate of Ground Water Recharge

\begin{tabular}{|l|c|c|}
\hline Category & No. of Persons & Percent \\
\hline Above 5 Feet & 15 & 3.0 \\
\hline 1 to 4 Feet & 37 & 7.4 \\
\hline 1 to 3 Feet & 56 & 11.2 \\
\hline 1 to 2 Feet & 118 & 23.6 \\
\hline Up to 1 Feet & 129 & 25.8 \\
\hline Below 1 Feet & 90 & 18.0 \\
\hline Don't Know & 55 & 11.0 \\
\hline \multicolumn{1}{|c|}{ Total } & 500 & 100 \\
\hline
\end{tabular}

Source: Field Survey

\section{Drinking Supply of Water}

Supply of water in rural area is maintained by PHED/Aapni Yojna department in the project area. Most of the villagers of study area are not satisfied with the supply system of department. Women are facing more problems because almost in all villages women need to fetch water from 200 meter to $2 \mathrm{~km}$. Only few male people fetch water from the source. Apart from this they are not getting water daily. Only 2.8 percent people reported that they are getting daily water. On the contrary 51.2 percent people are getting water once in a week. The situation is very disappointing. But they are helpless. Especially women have to face many difficulties. About 13.6 percent respondents reported that they are getting water twice in a month. Whereas 6.6 percent said that they are getting water once in a month. Rest of days they are dependent on other sources like buy water tank or use stored rainwater. Apart from this 25.8 percent told in a very angry way that there is no any fixed schedule to supply water (Table 16). There is no fix time to supply water by the concerned department. The concern department has no any water supply schedule or policy for villagers

Table 16: Drinking Supply of Water

\begin{tabular}{|l|c|c|}
\hline Category & No. of Persons & Percent \\
\hline Daily & 14 & 2.8 \\
\hline Weekly & 256 & 51.2 \\
\hline Fortnightly & 68 & 13.6 \\
\hline Monthly & 33 & 6.6 \\
\hline No Fix Schedule & 129 & 25.8 \\
\hline \multicolumn{1}{|c|}{ Total } & 500 & 100 \\
\hline
\end{tabular}

Source: Field Survey

\section{Leakage in Aapni Yojna Water Supply}

In some part of the study area it was observed that pipe line of water supply leaked especially at main valve point. Due to leakage the professional water suppliers collect the water and sell it high rates. Another issue is that potable water is wasted due to its proper maintenance and monitoring. The following table shows that 64.2 percent people are agreed that pipe line is 
broken in so many areas in the Taranagar block intentionally or due to its improper maintenance. Whereas 15.2 percent people reported that there is no any leakage issue in their village. About 20.6 percent people have not given any response (Table 17).

Table 17: Leakage in Aapni Yojna Water Supply

\begin{tabular}{|l|c|c|}
\hline Response & No. of Persons & Percent \\
\hline Yes & 321 & 64.2 \\
\hline No & 76 & 15.2 \\
\hline No Response & 103 & 20.6 \\
\hline \multicolumn{1}{|c|}{ Total } & 500 & 100 \\
\hline
\end{tabular}

Source: Field Survey

\section{Conclusion}

Over the past quarter century, global water problems have escalated. This study shows that the water problem in Taranagar block will worsen if not addressed as a matter of urgency. The people who reside in this area should be made acquainted with the consequences of the existing situation, especially the adoption of appropriate methods of conservative use, and the collective future planning of existing resources of ground water. The study also shows that poor recharging of aquifers and excessive extraction of ground water are the two main factors, which cause the water problem in the study area. The first factor is beyond the control of human efforts, while the second factor can be minimized through collective efforts. In this regard, a Master plan of water management and budgeting should be prepared at village level. To address these challenges governments, International organizations, NGOs, private sector companies etc. should make contributions to build capacities in multiple water emerging issues. In addition, political leaders, professionals, academicians, policy makers, students and others will require an understanding of water resources to save the mankind. The study recommends that each and every member of the society should be taught about the conservative use and to stop the wastage of water in their routine activities. In the area of agriculture, along with sprinkler-system of irrigation, irrigation drip system should also be adopted on large scale to minimize the requirement of irrigation water. Rain water should be stored in each and every house so that it can be used for domestic purpose reducing consumption of ground water. Aquifers should be recharged by preventing flowing rainwater by constructing appropriate recharge structures. The groundwater management rather than development is the major challenge facing the water resources, particularly in the dry land areas. Therefore, a focus on the development activities must be balanced by integrated management mechanism to achieve a sustainable utilization of groundwater resources, which is an important driver for the management for sustainable development in the area.

\section{References}

1. Central Arid Zone Research Institute (CAZRI) http://www.cazri.res.in

2. Central Ground Water Board (2005) Dynamic Ground Water Resources of India (As on March, 2004).

3. Central Ground Water Board (2011) Dynamic Ground Water Resources of India (As on 31st March 2009), Ministry of Water Resources, Govt. of India.

4. Central Ground Water Board (2012) Aquifer Systems of India, Ministry of Water Resources, Govt. of India.

5. Climate Change (2007) Impacts, Adaptation, and Vulnerability. Contribution of Working Group II to the Third Assessment Report of the Intergovernmental Panel on Climate Change (IPCC), M.L. Parry, O.F. Canziani, J.P. Palutikof, P.J. van der Linden and C.E. Hanson, Cambridge University Press.

6. Draft National Water Framework Bill, 2016, Govt. of India.

7. Gol (2012) Draft National Water Policy. Ministry of Water Resources, New Delhi. http://mowr.gov.in/writereaddata/linkimages/DraftNWP2012_English 9353289094.pdf.

8. Ground Water Report of Churu District (2005) Dept. of Ground Water, Govt. of Rajasthan. Jaipur

9. Human Development Report 2006: hdr.undp.org/hdr2006/

10. Jhanwar, M.L. (2001) Status Report on Assessment and Management of Water Resources in two Sun Catchments in Top sheet No. 54 A/4, Alwar District, Rajasthan. Department of Science and Technology (DST), Government of India, New Delhi.

11. Molden D., Sakthivadivel, R. (1999) Water accounting to assess uses and productivity of water. Water Resources Development 155, No.1 \& 2 
12. National Water Policy Document, 2002 and 2012, Ministry of Water Resources

13. NITI Aayog (2018) Composite Water Management Index.

14. Paul, G. (2017) Draft literature review response [Interview] (22 06 2017).

15. Planning Department, Government of Rajasthan www.planning.rajasthan.gov.in/

16. Prasad, S. N. et al. (1997) Impact of watershed management on runoff, water resource development and productivity of arable lands in South-Eastern Rajasthan. Indian Journal Soil Conservation, Vol. 25 No. 1.

17. Rajasthan State Action Plan on Climate Change (2012) Government of Rajasthan.

18. Rathore MS. (2005) Groundwater Exploration and Augmentation Efforts in RajasthanReview, Institute of Development Studies, Jaipur, Rajasthan.

19. Renault, D. (2002) Value of virtual water in food: Principles and virtues, Paper presented at UNESCO-IHE, Workshop on Virtual Water Trade, Dec. 12-13, Delft, the Netherlands,

20. Singh, S. et al., 2012. IWRM and Local Level Planning in Rajasthan. Special Study Series, Rajastan Study. European Union State Partnership Programme.

21. State Eleventh Plan (2007-2012), Mid-Term Review Document, Planning Department, Government of Rajasthan

22. State Water Policy Document, (2010) State Water Resource Planning Department, Government of Rajasthan

23. UNESCO-IHE (2009) Capacity Development for Improved Water Management, The Netherlands

24. UNICEF, 2017. Progress on drinking water, sanitation and hygiene: 2017 update and SDG baselines.

25. UN-Water: www.unwater.org

26. Vision-2025 for Rajasthan (2004) Central Ground Water Board, Western Region. Jaipur, India.

27. World Health Organization (2014) Joint Water Supply and Sanitation Monitoring Programme. Progress on drinking water and sanitation, WHO, Geneva.

28. World Water Council (2000)

29. World Water Day 2007: www.worldwaterday07.org

30. www.unesco.org/water/wwap/wwdr2/ 